\title{
Sensitive Spectrophotometric Determination of Tetracycline Hydrochloride Indosage forms using Sodium Nitroprusside and Hydroxylamine Hydrochloride
}

\author{
Hind Hadi and Ghadah Fadhil \\ Department of Chemistry, College of Science, Baghdad University, Baghdad-Iraq.
}

\begin{abstract}
An optimized and validated spectrophotometric method has been developed for the determination of Tetracycline hydrochloride $(\mathrm{TCH})$ in pharmaceutical formulations. The method is based on the reaction between $\mathrm{TCH}$, sodium nitroprusside and hydroxylamine hydrochloride in alkaline medium. The product absorbed maximally at $529 \mathrm{~nm}$. Beer's law is obeyed in the working concentration range of 2-60 $\mu \mathrm{g} \mathrm{mL}^{-1}$ with apparent molar absorptivity of $5.049 \times 10^{3} \mathrm{~L} \mathrm{~mol}^{-1} \mathrm{~cm}^{-1}$ and Sandell's sensitivity of $0.0952 \mu \mathrm{g} \mathrm{cm}^{2} / 0.001$ absorbance unit. The proposed procedure was applied successfully for estimation of drug in different commercial forms. The proposed method was applied to the determination of the studied drug in pharmaceutical formulations and the results demonstrated that the method is equally accurate and precise as the official method as found from the $\mathrm{t}$ - and F-values.
\end{abstract}

Keywords: Tetracycline hydrochloride, hydroxylamine hydrochloride, spectrophotometric.

\section{Introduction}

TCH is a broad-spectrum antibiotic prepared from the cultures of certain streptomyces species. Chemically, TCHis:4s(48,1 $\alpha, 4 \mathrm{a} \alpha, 5 \mathrm{a} \alpha, 6 \beta, 12 \mathrm{a} \alpha)$ )-4-(dimethylamino)1,4,4a,5,5a,6,11,12a-octahydro-3,6,10,12,12apentahydroxy-6-methyl-1,11-dioxo-2-

naphthacene-carboxamide monohydrochloride. Tetra-cyclines are active against a wide range of gram-negative and gram-positive organisms [1]. Several analytical methods have been reported for the determination of $\mathrm{TCH}$ in raw material and dosage forms include spectrophotometry [2,3], flow injection[4], voltametry [5], and HPLC methods [6].

Several visible spectrophotometric methods [7-9] are available for the evaluation of THC in pharmaceuticals; however, many of these procedures suffer from some drawback, such as poor sensitivity, requiring heating, extraction step or use of organic solvents, critical working conditions and are hence unsatisfactory for routine analysis. The present study describes the development of spectrophotometric method based on reaction between TCH and hydroxylamine hydrochloride (HAH) in the presence of sodium nitroprusside(SNP) in alkaline medium to form an intense dark red color product which shows an absorption maximum at $529 \mathrm{~nm}$. The analytical procedure is simple, reproducible and accurate. It has been satisfactorily applied for the determination of $\mathrm{TCH}$ in pure and dosage forms.

\section{Experimental}

\subsection{Apparatus}

All spectral and absorbance measurements were carried out on a UV/visible-260 digital double beam recording spectrophotometer using 1-cm silica cell.

\subsection{Reagents}

- Standard tetracycline hydrochloride solution, M.wt. $=480.9 \mathrm{~g} / \mathrm{moL}$ : stock solution $\left(1000 \mu \mathrm{g} \mathrm{mL}^{-1}\right)$ was prepared by dissolving $0.1000 \mathrm{~g}$ of the pure compound (kindly provided from state company for Drug Industries and Medical Appliance, SDI, Samara. Iraq) in a sufficient amount of distilled water and diluted to $100 \mathrm{~mL}$ in a volumetric flask with the same solvent. Working solution $\left(200 \mu \mathrm{g} \mathrm{mL}^{-1}\right)$ was prepared by a simple dilution with the same solvent.

- Sodium nitroprusside solution, M.wt.= 298g/moL(BDH,UK):0.2\%(W/V) prepared by dissolving $0.2000 \mathrm{~g}$ of SNP in $100 \mathrm{~mL}$ of distilled water.

- Hydroxylaminehydrochloridesolution, M. $w t .=69 \mathrm{~g} / \mathrm{moL} \quad$ (Merck, Darmstadt, Germany): $20 \mathrm{mM}$, prepared by dissolved 
$0.1389 \mathrm{~g}$ of $\mathrm{HAH}$ in $100 \mathrm{~mL}$ of distilled water.

- Sodium hydroxide (BDH, UK): 100mM, prepared by dissolving $0.4000 \mathrm{~g}$ of the base in a $100 \mathrm{~mL}$ of distilled water.

- Pharmaceutical preparations, Two types of capsules (MEHECO/ China and NDI/Iraq $250 \mathrm{mg})$ and one type of ointment (3\% Awamedica /Iraq )containing TCH have been analyzed.

\subsection{General batch procedure}

An aliquot of sample containing 20 $600 \mu \mathrm{g}$ of $\mathrm{TCH}$ was transferred into a series of $10 \mathrm{~mL}$ standard flasks $\left(2-60 \mu \mathrm{g} \mathrm{mL}{ }^{-1}\right)$. A volume of $1.5 \mathrm{~mL}$ of $0.1 \mathrm{M} \mathrm{NaOH}, 0.5 \mathrm{~mL}$ of $0.2 \%(\mathrm{~W} / \mathrm{V})$ of SNP solution and $0.5 \mathrm{~mL}$ of $20 \mathrm{mM}$ of HAH solution were added. The contents of the flasks were diluted to the mark with distilled water, mixed well and left for $30 \mathrm{~min}$. The absorbance was measured at $529 \mathrm{~nm}$ (at room temperature $25^{\circ} \mathrm{C}$ ) against reagent blank containing all materials except TCH.A calibration graph was drawn and the regression equation calculated. For the optimization of conditions and in all subsequent experiments, a solution of $400 \mu \mathrm{g}$ was used and the final volume was $10 \mathrm{~mL}$ (i.e. $40 \mu \mathrm{g} \mathrm{mL}^{-1}$ ).

\subsection{Procedure for capsules and ointment}

Capsules samples: An accurately weigh amount of 10 powdered capsules equivalent to $10 \mathrm{mg}$ of the pure drug was dissolved in $10 \mathrm{~mL}$ distilled water and transferred into $50 \mathrm{~mL}$ volumetric flask and completed to the mark with the same solvent . The flask with its contents was shaked well and filtered to obtain $200 \mu \mathrm{g} \mathrm{mL}^{-1}$.The measurements were carried out at $529 \mathrm{~nm}$ as described earlier under general procedures.

Ointment samples: The contents of five tubes of ointment were mixed. The accurately weighed amount of ointment equivalent to $30 \mathrm{mg}$ of TCH was dissolved in $20 \mathrm{~mL}$ diethyl ether and extracted with three $20 \mathrm{~mL}$ of $0.01 \mathrm{M}$ $\mathrm{HCl}$. The solution was filtered into a $100 \mathrm{~mL}$ volumetric flask, the residue was washed with $0.01 \mathrm{M} \mathrm{HCl}$ and diluted to volume with the same solvent to obtain $300 \mu \mathrm{g} \mathrm{mL}^{-1}$ of $\mathrm{TCH}$.

\section{Results and Discussion}

The parameters affecting mainly on the sensitivity and stability of the coloured product resulting from the reaction of $\mathrm{TCH}$ with SNP in the presence of $\mathrm{HAH}$ in alkaline medium were carefully studied and optimized .In the present work, an orderly study of the effects of different parameters were established by changing one parameter at a time and keeping the others fixed by observing the effect produced on the absorbance of the colored species.

The effect of various parameters such as time, temperature, volume and strength of $\mathrm{SNP}, \mathrm{HAH}, \mathrm{NaOH}$ reagents, order of addition of reagents on color development of the colored species were studied and optimized. The absorption spectrum of the dark red product is given in Fig.(1). The maximum absorption at $529 \mathrm{~nm}$ was used in all subsequent experiments.

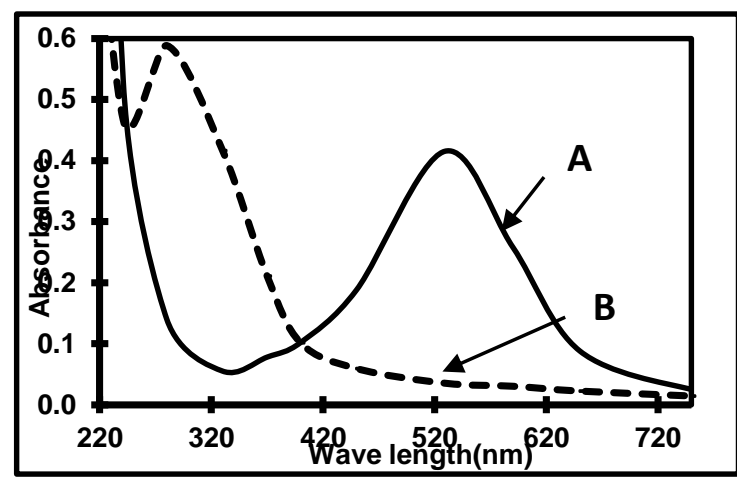

Fig. (1) Absorption spectra of A (40 $\left.\mu \mathrm{g} m L^{-1}\right)$ of TCH treated as described under procedure and measured against blank and $B$ the reagent blank measured against distilled water.

The procedure is based on an aromatic electrophilic reaction, which is represented by Scheme (1). In strongly alkaline mediums, phenol is converted to phenolate. Thus, the electrophilic reaction can take place more easily because the benzene ring becomes very active due to the presence of the negative oxygen $\left(\mathrm{O}^{-}\right)$. According to the pure organic chemistry theory, the sites that the nitroso group $\left({ }^{+} \mathrm{NO}\right)$ of the SNP attacks the phenolate molecule at para- or or tho-positions and in TCH case from para-position. The electrophilic or electrophobic properties of the substituent in the benzene ring affect the reaction extension, 
and consequently the sensitivity of the method [10].

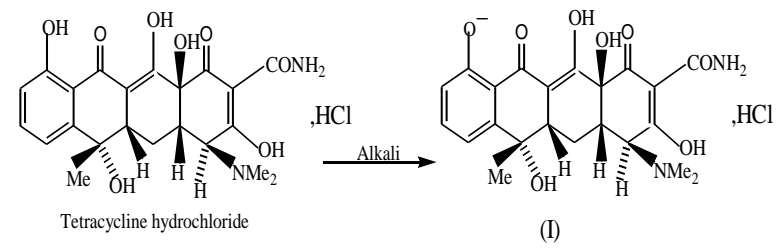

$$
\begin{aligned}
{\left[\mathrm{Fe}(\mathrm{CN})_{5} \mathrm{NO}\right]^{2-} } & +2(\mathrm{I})+6 \mathrm{NH}_{2} \mathrm{OH}+6 \mathrm{OH}^{-} \\
& \rightleftharpoons\left[\mathrm{Fe}_{2}(\mathrm{CN})_{10}\right]^{10-}+3 \mathrm{~N}_{2}+12 \mathrm{H}_{2} \mathrm{O}
\end{aligned}
$$

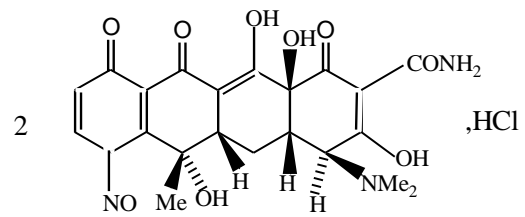

\section{Scheme (1) Proposed mechanism of the reaction between TCH and SNP.}

\section{Study of the optimum reaction conditions}

The effect of various parameters on the absorption intensity of the formed product was studied and the reaction conditions were optimized. All the optimum conditions were established by changing one parameter at a time and keeping the others fixed by observing the effect produced on the absorbance of the colored species.

\subsection{Effect of the volume of HAH}

$\mathrm{HAH}$ (reducing agent) was found to be very essential for the reaction between $\mathrm{TCH}$ and SNP. The effect of the different volumes ( 0.3 to $2.5 \mathrm{~mL}$ ) of $20 \mathrm{mM}$ HAH solution on the formation of the colored product was studied. The results (Fig.(2)) show that $0.5 \mathrm{~mL}$ of the solution was enough to obtain the maximum absorbance, and it was used in the subsequent experiments.

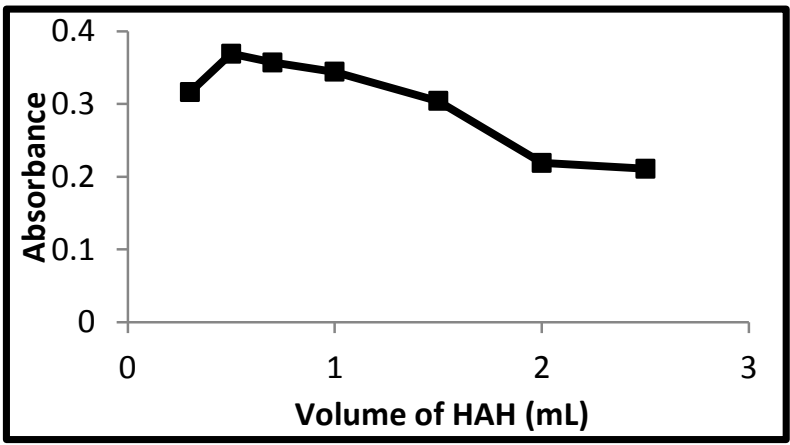

Fig.(2) Effect of reagent volume.

\subsection{Effect of the volume of SNP}

The effect of the different volumes ( 0.3 to $2.5 \mathrm{~mL}$ ) of $0.2 \%(\mathrm{w} / \mathrm{v})$ of SNP solution on the formation of the colored products for $\mathrm{TCH}$ was studied. The absorbance of the reaction product was increased on using up to $0.5 \mathrm{~mL}$ for $\mathrm{TCH}$, further increase in volume resulted in a decrease in the absorbance of the reaction product, thus $0.5 \mathrm{~mL}$ of $0.2 \%(\mathrm{w} / \mathrm{v})$ of $\mathrm{SNP}$ were adequate for the maximum absorbance (Fig.(3)).

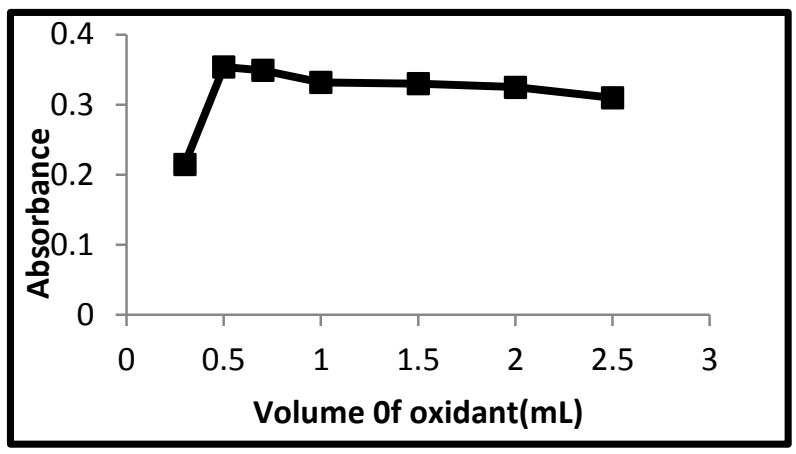

Fig.(3) Effect of SNP volume.

\subsection{Effect of the base}

Preliminary experiments explained that the dark-red dye product was performed more efficiently in a slightly basic medium. Therefore, the effect of different kinds of basic solutions was studied. Maximum sensitivity and stability were obtained only on using sodium hydroxide as an alkaline medium (Fig.(4)).

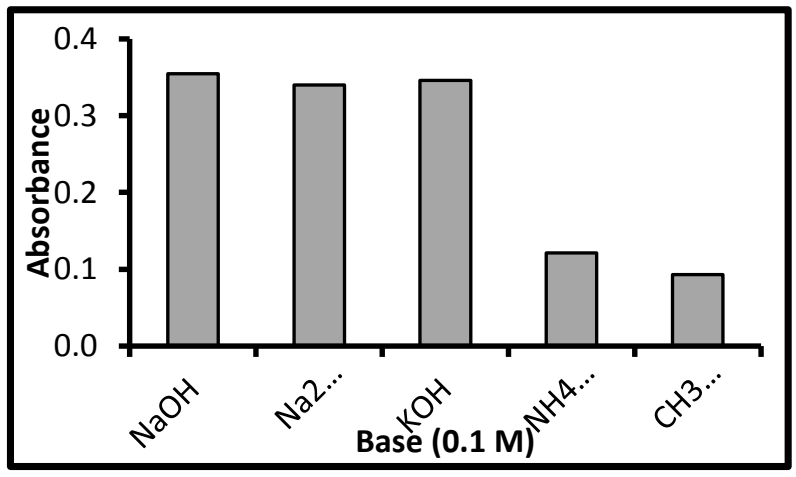

Fig.(4) Effect of base.

The effect of the different volumes ( 0.3 to $2.5 \mathrm{~mL}$ ) of $0.1 \mathrm{M}$ of sodium hydroxide solution on the formation of the colored product was studied. It was found that $1.5 \mathrm{~mL}$ gave a maximum absorbance, and it was used in the subsequent experiments. 


\subsection{Effect of order of addition}

Different orders of addition of reagents were experimented and it was found that the order of addition of reagents cited under general procedure $(\mathrm{TCH}+\mathrm{NaOH}+\mathrm{SNP}+\mathrm{HAH})$ was optimum and was used in all subsequent experiments.

\subsection{Effect of reaction time}

In spite of the rapid color development (formed immediately) the color intensity reached a maximum after $\mathrm{TCH}$ solution had been reacted with SNP and $\mathrm{HAH}$ in the presence of sodium hydroxide for $30 \mathrm{~min}$, therefore $30 \mathrm{~min}$ development time was selected as optimum in the general procedure. The color obtained was stable for $90 \mathrm{~min}$.

\subsection{Effect of temperature}

The effect of temperature on the color intensity of the products was studied. Maximum absorbance was obtained when the color was developed at room temperature $\left(25^{\circ} \mathrm{C}\right)$ more than when the color was developed in an ice-bath $\left(5^{\circ} \mathrm{C}\right)$ or in a waterbath $\left(45^{\circ} \mathrm{C}\right)$. In addition a loss in color intensity and stability were observed with increase of the temperature, therefore, it is recommended that the color reaction should be carried out at room temperature $\left(25^{\circ} \mathrm{C}\right)$.

\subsection{Stoichiometry of the reaction}

The stoichiometry of the reaction between each TCH and SNP was investigated under the recommended optimum conditions and applying Job's method [11].Volumes of 0.5$4.5 \mathrm{~mL}$ of $5.198 \times 10^{-4} \mathrm{M}$ portions of SNP were coupled with corresponding $4.5-0.5 \mathrm{~mL}$ of $5.198 \times 10^{-4} \mathrm{M}$ TCH solution to give a total volume of $5 \mathrm{~mL}$.The results obtained (Fig.(5)) showed that a 1:1 (TCH: SNP) product was formed between TCH and SNP.

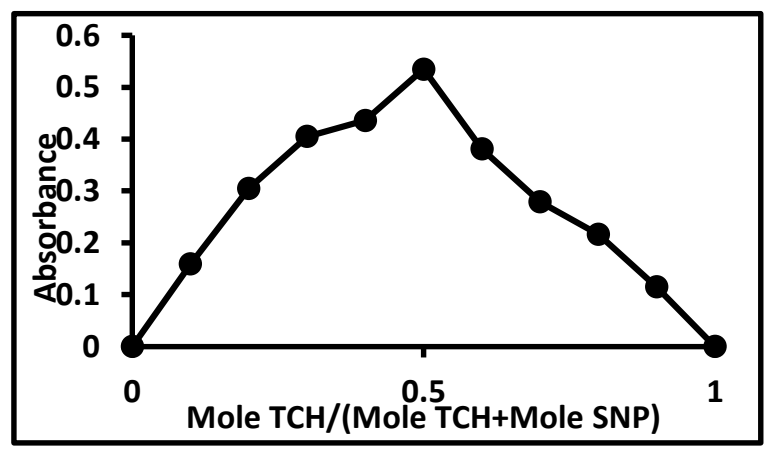

Fig.(5) Job's method for the complex produced.

\subsection{Calibration graph}

Employing the conditions described under general procedure, a linear calibration graph Fig.(6) for $\mathrm{TCH}$ was obtained, which shows that Beer's law obeyed over the concentration range of $20-600 \mu \mathrm{g} / 10 \mathrm{~mL}$ or $2-60 \mathrm{ppm}$ with a correlation coefficient of 0.9994 . The conditional molar absorptivity of the product formed with $\mathrm{TCH}$ was found to be $5.049 \times 10^{3} \mathrm{~L} \cdot \mathrm{mol}^{-1} \cdot \mathrm{cm}^{-1}$ with reference to the $\mathrm{TCH}$ and sandell sensitivity was $0.0952 \mu \mathrm{g} . \mathrm{cm}^{-2}$.

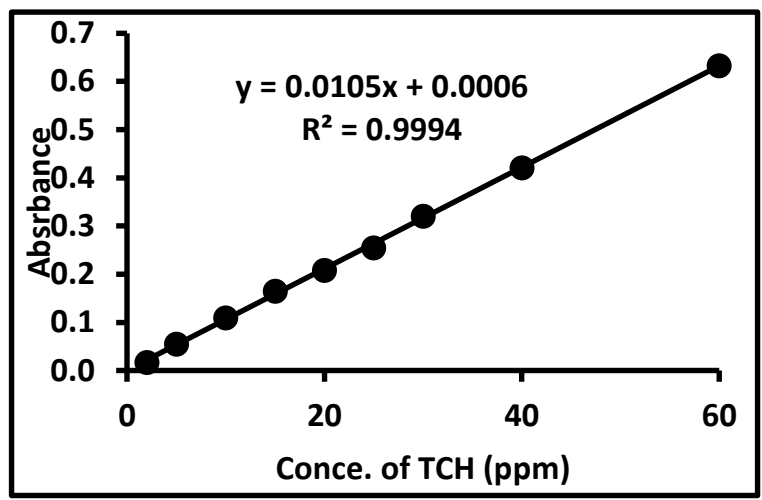

Fig.(6) Calibration curve.

The optical characteristics, such as Beer's law, molar absorbativity, and correlation coefficient and other analytical data are summarized in Table (1).

\section{Table (1)}

Analytical data obtained from proposed method.

\begin{tabular}{||c||c||}
\hline Parameter & Value \\
\hline \hline Beer's Low limits $\left(\mu \mathrm{g} \cdot \mathrm{mL}^{-1}\right)$ & $2-60$ \\
Molar absorbativity $\left(\mathrm{L} \cdot \mathrm{mole}^{-1} \cdot \mathrm{cm}^{-1}\right)$ & $5.05 \times 10^{3}$ \\
$\left(\varepsilon=\mathrm{b} \times \mathrm{M} \times 1000 ; \mathrm{M}=\mathrm{M} \cdot \mathrm{wt}\left(\mathrm{g} \mathrm{mol}^{-1}\right)\right)$ & \\
Sandell's sensitivity $\left(\mu \mathrm{g} \cdot \mathrm{cm}^{-2}\right), \mathrm{S}$ & 0.0952 \\
per 0.001 absorbance unit, $\mathrm{S}=\mathrm{M} / \varepsilon$ & \\
Slope(b) & 0.0105 \\
Intercept $(\mathrm{a})$ & 0.0006 \\
Correlation coefficient $(\mathrm{r})$ & 0.9994 \\
$\lambda_{\max }(\mathrm{nm})$ & 529 \\
R.S.D $(\%)$ & $<1.70$ \\
Limit of Detection $\left(\mu \mathrm{g} \cdot \mathrm{mL}^{-1}\right)$ & 0.574 \\
Limit of Quantitation $\left(\mu \mathrm{g} \cdot \mathrm{mL}^{-1}\right)$ & 1.739 \\
\hline
\end{tabular}


Limit of Detection (LOD) and Limit of Quantitation (LOQ) were calculated according to the $3 \mathrm{SD}_{\mathrm{B}} / b$ and $10 \mathrm{SD}_{\mathrm{B}} / b$ criterions, respectively [13] where $\mathrm{SD}_{\mathrm{B}}$, is the standard deviation of the absorbance $(n=10)$ of the blank determinations and $b$ is the slope of the corresponding calibration curve.

\subsection{Accuracy and precision}

The accuracy and precision of the proposed method were determined at three concentration levels of TCH by analyzing five replicate samples of each concentration. The relative standard deviations (RSD) for the results did not exceed $1.7 \%$ (Table (2)), proving the high reproducibility of the results and the precision of the method. This good level of precision was suitable for quality control analysis of $\mathrm{TCH}$ in its pharmaceutical forms.

Table (2)

Accuracy and precision of the proposed method.

\begin{tabular}{|c|c|c|c|}
\hline \multicolumn{2}{|c|}{ Amount of TCH $\left(\mu g \cdot \mathrm{mL}^{-1}\right)$} & \multirow{2}{*}{$\begin{array}{l}\text { R.S.D } \\
(\%)^{*}\end{array}$} & \multirow{2}{*}{$\begin{array}{c}\text { Recovery } \\
(\%) *\end{array}$} \\
\hline Present & Found & & \\
\hline 20.00 & 19.75 & -1.25 & 98.75 \\
\hline 30.00 & 30.51 & +1.70 & 101.70 \\
\hline 40.00 & 40.04 & +0.10 & 100.10 \\
\hline
\end{tabular}

\section{Analytical Applications}

The suggested method was applied to the quantitative determination of $\mathrm{TCH}$ in pharmaceutical formulations. Two types of capsules and one type of ointment containing TCH have been analyzed and they gave a good accuracy and precision as shown in Table (3). The proposed method was compared successfully with the British pharmacopeia's standard method, since F-test and t-test showed that there was no significant difference between the proposed and official methods [12].

Table (3)

Application of the proposed method for the determination of TCH in pharmaceutical preparations.

\begin{tabular}{|c|c|c|c|c|c|c|}
\hline \multirow{2}{*}{$\begin{array}{l}\text { Pharmaceutical } \\
\text { form }\end{array}$} & \multicolumn{2}{|c|}{$T C H\left(\mu g m L^{-1}\right)$} & \multirow{2}{*}{$\begin{array}{l}R S D \\
(\%)^{*}\end{array}$} & \multirow{2}{*}{$\begin{array}{c}\text { Recovery } \\
(\%)^{*}\end{array}$} & \multirow{2}{*}{$\begin{array}{l}\text { Average } \\
\text { Recovery }\end{array}$} & \multirow{2}{*}{$\begin{array}{c}\text { Official } \\
\text { method [12] } \\
\text { recovery } \\
\end{array}$} \\
\hline & Taken & Found & & & & \\
\hline \multirow{3}{*}{$\begin{array}{c}\text { Tetracycline } \mathrm{HCl} \text { capsules } \\
\text { 250mg } \\
\text { (MEHECO/ China) }\end{array}$} & 10.00 & 9.91 & 1.25 & 99.10 & \multirow{3}{*}{99.14} & 99.00 \\
\hline & 20.00 & 19.62 & 1.54 & 98.10 & & \\
\hline & 30.00 & 30.07 & 0.99 & 100.23 & & \\
\hline \multirow{3}{*}{$\begin{array}{c}\text { Ninacycline } \mathrm{HCl} \text { capsules } \\
250 \mathrm{mg} \\
(\mathrm{NDI} / \mathrm{Iraq}) \\
\end{array}$} & 10.00 & 9.74 & 2.18 & 97.40 & \multirow{3}{*}{98.03} & 99.50 \\
\hline & 20.00 & 19.73 & 1.35 & 98.65 & & \\
\hline & 30.00 & 29.41 & 0.91 & 98.03 & & \\
\hline \multirow{4}{*}{$\begin{array}{c}\text { Tetracycline } \mathrm{HCl} \text { ointment } \\
3 \% \\
\text { (Awamedica/ Iraq) }\end{array}$} & 10.00 & 9.79 & 1.96 & 97.90 & \multirow{3}{*}{97.33} & 98.02 \\
\hline & 20.00 & 19.39 & 2.11 & 96.95 & & \\
\hline & 30.00 & 29.14 & 1.11 & 97.13 & & \\
\hline & & $\begin{array}{l}(\mathbf{t}=0.692)^{* * *} \\
(\mathbf{F}=1.938)^{* *}\end{array}$ & & & & \\
\hline
\end{tabular}

* Average of four determinations.

** Theoretical values at confidence level $95 \%, t=2.571$ and $F=9.28$. 


\section{Conclusion}

The proposed method is superior to other reported methods by showing good sensitivity, and low detection limit. In addition to competitive precision and sensitivity, the proposed procedure shows relevant selectivity allowing analysis without separation steps. The proposed method is advantageous when it is compared with other colorimetric methods, in having higher sensitivity. Furthermore, the proposed method does not require $\mathrm{pH}$ control or elaboration of treatment and procedure, which are usually associated with chromatographic methods and other colorimetric methods.

\section{References}

[1] Abernethy, D.R; "Mosby's Drug Consult", Mosby. Inc. London, pp2687; 2002.

[2] Abdel-Kahlek, M.M. and M.S. Mahrous, "Spectrophotometric determination of tetracyclines and cephalosporins with ammonium vanadate". Talanta, 30, 792797, 1983.

[3] khodavirdilo1, B., Samadi, N., hodavirdilo, S. "A Cheap and Simple Method for Determining of Antibiotics in Pharmaceutical Products by Using Prussian Blue Reaction" Asian J. Biomed. Pharma. Sci. 2 (14), 6571, 2012.

[4] Rufino, J. L. ; Weinert, P. L.; Pezza H. R.; Pezz, L., "Flow-injection spectrophotometric determination of tetracycline and doxycycline in pharmaceutical formulations using chloramine-T as oxidizing agent" Quim. Nova, 32(7), 1764-1769, 2009.

[5]Wang, J.; Peng, T., Bioelectrochem. Bioenergy., "Trace measurements of tetracyclines using adsorptive stripping voltammetry" 15(2),147-156, 1986.

[6]Shalaby, A.R.; Salama, N. A.; Abou-Raya, S.H.; Emam, W.H.; Mehaya F.M. "Validation of HPLC method for determination of tetracycline residues in chicken meat and liver" Food Chemistry,124(4), 1660-1666, 2011.

[7] Fahelelbom, K. M.S., "Analysis of Certain Tetracyclines and Oxytetracyclines through Charge Transfer Complexation" American J. Pharma. Toxico. 3 (3): 212-218, 2008.
[8] Suha, U., "Colorimetric determination oftetracycline derivatives in pharmaceutical preparations." J. Assoc. Anal. Chem., 72: 242244, 1989.

[9]. Emara, K.M., H.F. Askel and G.A. Saleh, "Spectrophotometric determination of tetracyclineand oxytetracycline in pharmaceutical preparations". Talanta, 38: 1219-1221, 1991.

[10] Kang, C.; Wang, Y.; Li, R.; Du, Y. ; Li, J.; Zhang, B.; Zhou, L.; Du, Y. "A modified spectrophotometric method for the determination of trace amounts of phenol in water." Microchem.J. 64, 161164, 2000.

[11] Braunm. R.D "Introduction to instrumental analysis" Mc-Graw-Hillm NewYork, pp.291, 1987.

[12] British pharmacopoeia, H.M. Stationary office, London, 1993.

[13] Long, G.L.; Winefordner, J.D. "Limit of Detec tion" Anal. Chem. 55,712, 1983.

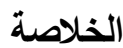

بتضمن البحث نطوير طريقة طيفية سريعة وحساسة

للتقدير الكمي للمقادير الضئيلة من مستحضر التتراسايكلين

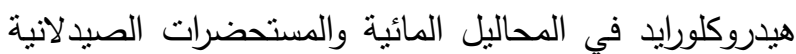

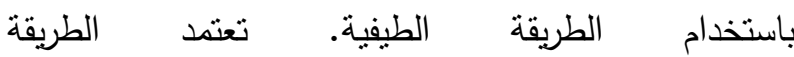

على التفاعل بين التتراسايكلين وكاثف نتروبروسيد الصوديوم

وهيدروكسيل امين هيدروكلورايد في الوسط القاعدي. بلغ مدى لئرئ

الخطية r-.7 مايكروغرامامل من التتراسايكلين حيث نم

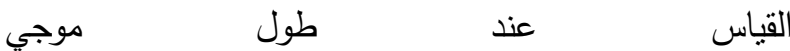

9 9 9 نانومترا. قيمة الامتصاصية المولارية وحساسية ساندل

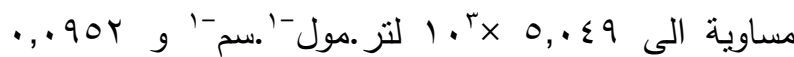

مايكروغرام .سم-r على التوالي .طبقت الطريقة المقترحة

بنجاح لتقدير الدواء في مستحضراته الصيدلانية حيث اثتتت

النتائج من خلال اختباري t g بعدم وجود اختلاف بالدقة والتوافقية بين الطريقة المقترحة والطريقة القياسية. 